\title{
The Biomass Coal Fermented (BCF) Briquette as an Alternative Fuel
}

\author{
Dyah Marganingrum ${ }^{1}$, Lenny Marilyn Estiaty ${ }^{2}$, Chandra Irawan ${ }^{3}$, and Hidawati ${ }^{4}$ \\ \{dmarganingrum@yahoo.com ${ }^{1}$ \} \\ Research Centre for Geotechnology - Indonesian Institute of Sciences \\ Nusantara Energy Media Study Group $1,2,3,4$
}

\begin{abstract}
Bottom ash (BA) is a waste categorized as B3, so the disposal process requires special handling and costs. The use of coal as fuel which is increasing in various industries, especially the textile industry, has caused BA generation to be an interesting issue to study. On the other hand, economic activities and production in the urban area leaves problems in the form of municipal solid waste (MSW). This paper aims to utilize both of two wastes to become a fuel product as well as being one of the solutions to environmental problems. The method used in this study is the manufacture of briquettes made from BA and fermented of MSW called Biomass Coal Fermented (BCF) briquettes. Briquette printing uses starch adhesive. The formulation used is $60 \%$ BA and $40 \%$ MSW. The briquette product then is tested in the boiler- 1 of textile industry with a fluidized bed type where the BA produced. The results showed that with a $10 \%$ substitution of briquettes on the use of coal, combustion efficiency increased by $48 \%$. The results of air emission measurements show values below the air quality standard for particulates, $\mathrm{SO}_{2}$, and $\mathrm{NO}_{2}$. And when compared to boiler- 2 without substitution ( $100 \%$ using the same coal) there was an increase in particulate matter and $\mathrm{NO}_{2}$ respectively by $28 \%$ and $2 \%$. But there was a decrease in $\mathrm{SO}_{2}$ value as much as $67 \%$. From the results of this temporary trial, the potential of BCF briquettes can be an alternative fuel in the industry while it could reduce the generating BA and MSW.
\end{abstract}

Keywords: Air quality standards, Bottom ash, Emission, Fermentation, Municipal solid waste

\section{Introduction}

Until 2050 The National energy needs continue to increase in accordance with economic growth, population, energy prices, and government policies. The industrial sector is expected to remain dominant as the biggest energy user in the long run with an average growth of $6.1 \%$ per year for 2016-2050. The industrial sector is a productive sector whose development is continuously encouraged in order to improve the national economy. The share of the final energy needs of the industrial sector is expected to increase from $35.5 \%$ in 2016 to $46.8 \%$ in 2050.

Government Policy through Presidential Regulation Number 22 Year 2017 Regarding the National Energy General Plan states that one of Indonesia's energy development priorities is to make coal a mainstay of national energy supply. Although fuel diversification is the Government's policy to face the decline in national fossil energy reserves, the use of coal remains the last resort after maximizing the use of renewable energy. 
Indonesia's potential for new and renewable energy (EBT) is quite large, with a variety of diverse types of energy. However, the potential of EBT has not been optimally developed due to various implementation obstacles, such as high investment costs, relatively low technological efficiency, geographical location, and social factors of people as energy users.

On this basis this research was conducted to produce a fuel substitute product that is relatively inexpensive but with relatively high efficiency and can be used by local users. The intended product is the Biomass Coal Fermented (BCF) briquette with a mixture of bottom ash and biomassa from the municipal solid waste which fermented.

Studies on bottom ash utilization has not been done as much as the use of fly ash[1] because it is still limited to civil engineering application such as road construction, dykes, building materials, geo-polymer applications and in cement production [2-4]. Apart from being classified as hazardous and toxic waste (LB3), bottom ash still contains fixed carbon but is poor in volatile matter. Other studies shows that bottom ash still has caloric value of up to $3,000 \mathrm{kcal} / \mathrm{kg}$, so it is still has the potential to be reused [5-7]. That bottom ash can be used again as a solid fuel, so it is necessary to add volatile matter that can be obtained from various types of biomass sources.

Research on biomass as an energy source has been widely carried out. Patabang (2012) tried to make biomass briquettes from the raw material of rice husks by the process of pyrolysis or carbonization and drying under the sun for 8 hours. This study produced a calorific value of $2789 \mathrm{cal} / \mathrm{g}$. Karim et al. (2014) also made biobriquettes made from water hyacinth using carbonation methods.

This carbonation process is considered less economical because it requires additional energy from the outside. For this reason the "peuyeumisasi" method was developed. "Peuyeumisasi" method is a natural process usage which is able to convert waste into solid fuel without causing odors and leachate. This peuyeumization process is carried out by microbiological ripening aimed at accelerating waste degradation. The process is carried out aerobically in a bamboo cage by utilizing the activity of a bioactivator containing certain bacteria to eliminate odors and accelerate the shrinkage of the volume of waste.

\section{Material and Method}

\subsection{Making Biomass Fermented Using the "Peuyeumisasi" Method}

The biomass material used in this study is urban waste from Bandung district area, which is managed by DLH Bandung Regency and often called as Municipal Solid Waste (MSW). MSW used in this study has been through the scavenging process. Based on the identification results, the composition of MSW is 50\% organic and 50\% inorganic (percent by volume) and $90 \%$ organic and 10\% inorganic (percent by weight) (Figure 1). The inorganic of MSW consist of paper and various types of plastic.

The peuyeumisasi process is done within basket made form bamboo. The size of basket is 2.5 meters of length, 1 meter of width, and 1.2 meters of height $\mathrm{m}$ (Figure 2). However, the volume used is only $2.5 \mathrm{~m}^{3}$ for holding approximately 1 ton of MSW. Left space of basket for air volume to keep aerobically the "peuyeumisasi" process. The high of MSW in the basket is divided into 5 layers, each layer (height $\pm 20 \mathrm{~cm}$ ) is given an evenly distributed bioactivator. 


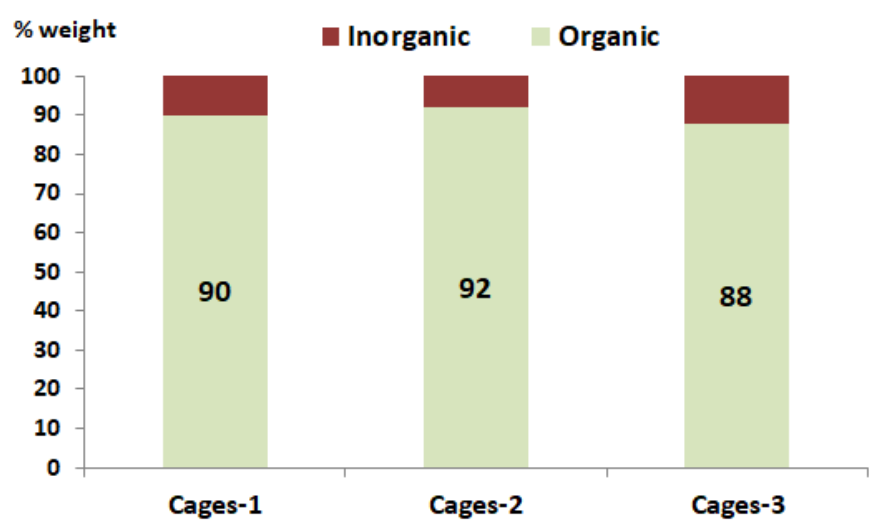

Fig. 1. Municipal solid waste composition which is used in this study.

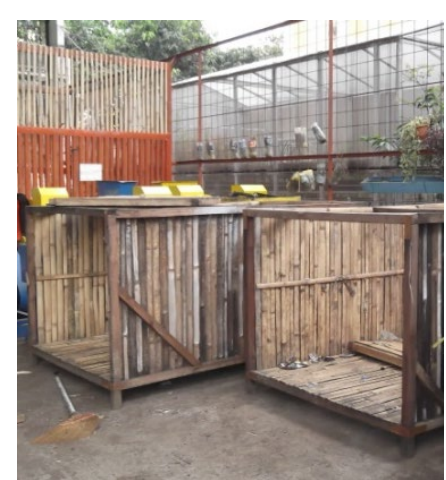

(a)

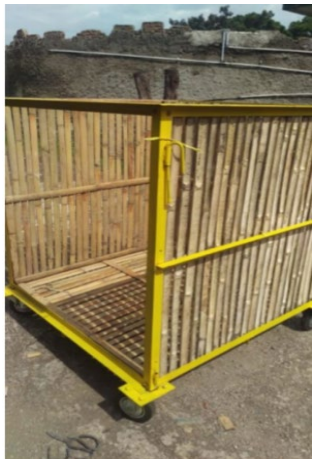

(b)

Fig. 2. Solid waste basket for "peuyeumisasi" proccessing.

(a) = simple basket; $(b)=$ basket modification for handling easily and strengthen

Waste that has been processed by "peuyeumisasi" method for approximately 7 days then removed from the basket to adjust with room temperature. We measured temperature and $\mathrm{pH}$ of MSW in the basket during the "peuyeumisasi" process. The next process is rough crusher then followed by fine crusher. The results of fine crusher is fermented biomass (BM) raw material that is ready to be mixed with bottom ash.

\subsection{Making BCF (Biomass Coal Fermented) Briquette}

Briquettes in this study are made from bottom ash (coal waste) and fermented MSW. The bottom ash used comes from coal burning ash from one of the textile industries in Bandung Regency. The two raw materials are mixed with a formulation of $60 \%$ bottom ash and $40 \%$ fermented waste. Both raw materials are mixed using $0.5 \%$ starch adhesive (amylum). Mixing the two raw materials is done homogeneously using a mixer. The homogeneous mixture is then 
printed into BCF briquettes in the pillows form. Some of the machines used in BCF formation are shown in Figure 3.

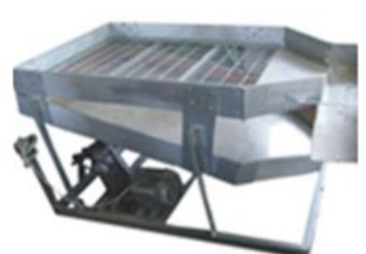

Sieving machine

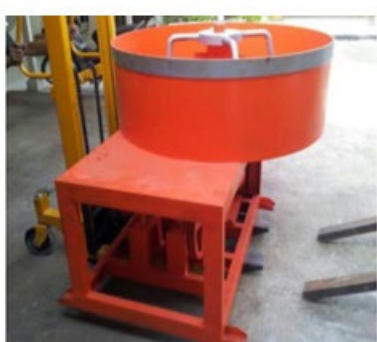

Mixer machine
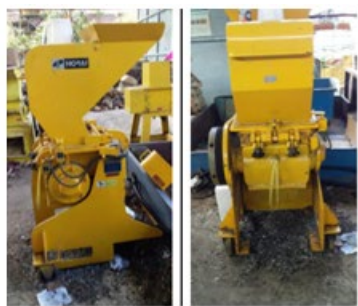

Rough crusher machine

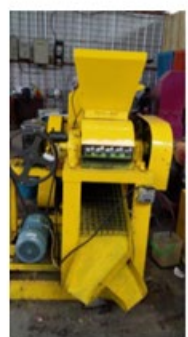

Briquette molding machine

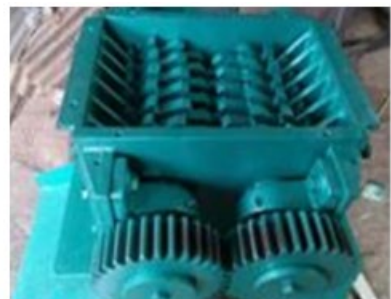

Smooth crusher machine

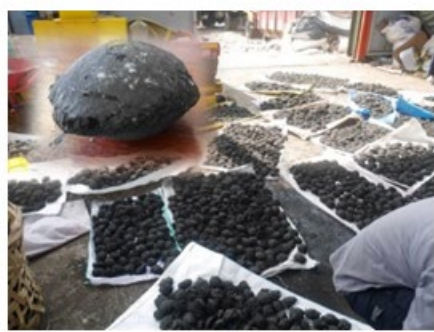

BCF briquettes

Fig. 3. Some tools and machines used in making BCF briquettes.

\subsection{The BCF Briquette Testing in The Textile Industry}

BCF briquettes were tested in a fluidized bed type boiler (Figure 4). The boiler is owned by one of the textile industries in Bandung Regency which is also the bottom ash source used in this study. BCF briquette substitution as fuel is only given at $10 \%$ of the use of existing fuel. Observations made during combustion of fuel are temperature, pressure, and exhaust emissions resulted from the combustion process.

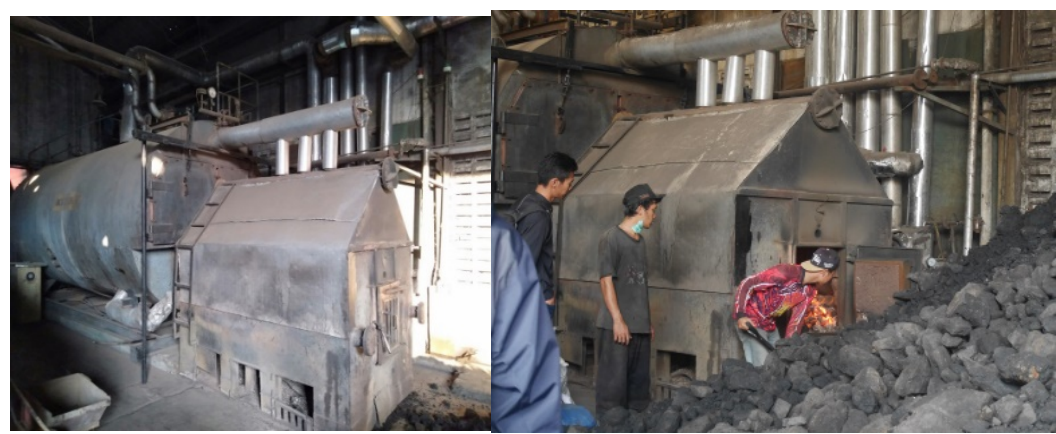


Fig. 4. Boiler (steam fluidized bed) used for BCF trial.

\section{Results and Discussion}

The formulation use of $60 \% \mathrm{BA}$ and $40 \% \mathrm{BM}$ based on the results of previous studies that provide optimal value, both in terms of caloric value, physical-chemical properties of BCF products, and the purpose of waste utilization.

Figure 5 shows that the 50\%:50\% formulation gives the maximum caloric value. This formulation can be used if the main purpose of making product is to increase the caloric value. In addition to the caloric value, waste reduction, both bottom ash and urban waste, is also an important target in this study. If purely using biomass briquettes with a calorific value of approximately $3000 \mathrm{cal} /$ gram [8], it still left problems in the bottom ash generation as hazardous and toxic waste (LB3). Meanwhile, if we use only bottom ash, the result of caloric value is very low, which is less than $2000 \mathrm{cal} /$ gram and has not been able to overcome the waste problem. Therefore, this study used an optimal formulation of $60 \%: 40 \%$ in order to achieve calorific value while reducing urban waste problem(Figure 6).

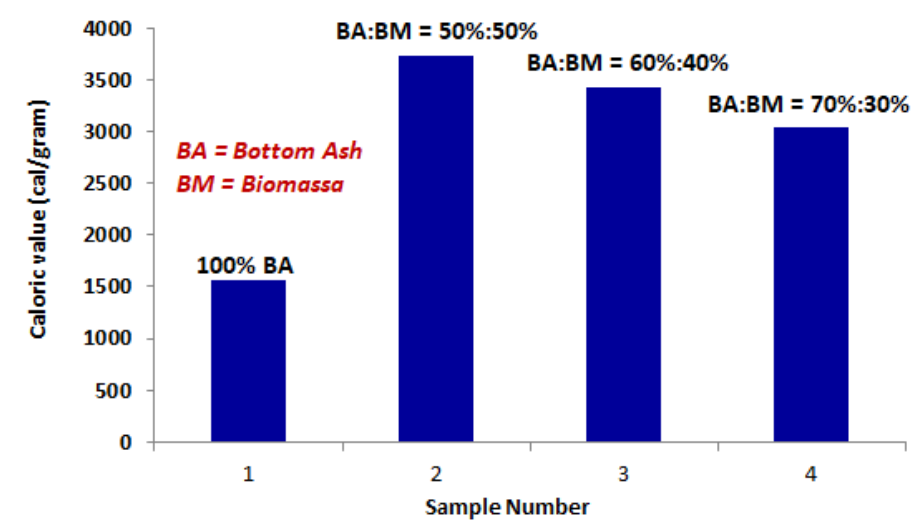

Fig. 5. Comparation of caloric value based on BA and BM ratio.

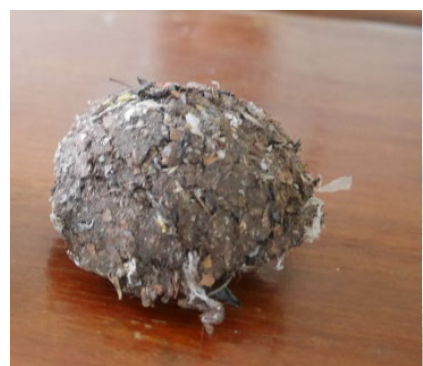

(a)

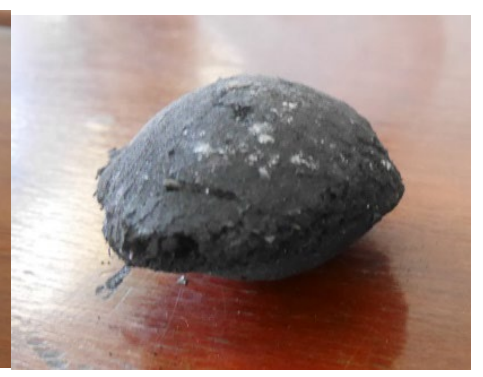

(b) 
Fig. 6. (a) $100 \%$ of biomassa; (b) $60 \%$ BA and $40 \%$ BM.

Proximate and ultimate analysis are the main parameters to determine whether a material is feasible or has potential for solid fuel. Proximate analysis is used to calculate the fuel characteristics in terms of water content (moisture), volatile matter content, fixed carbon and ash content in solid fuels. While the ultimate analysis is used to calculate the elemental composition of raw materials including the content of $\mathrm{C}, \mathrm{H}, \mathrm{O}, \mathrm{N}$ and $\mathrm{S}$. Both of these analyzes can affect the material quality as solid fuel [9-11]. Proximate analysis and calorific value are also examples of the main parameters is needed in characterizing briquettes or pellets that are rationally effectively used as fuel[9,12]. The proximate analysis results of BCF are shown in Table 1 and Figure 7.

Table 1. Proximate Analyses of Biomass Coal Briquettes (BCF).

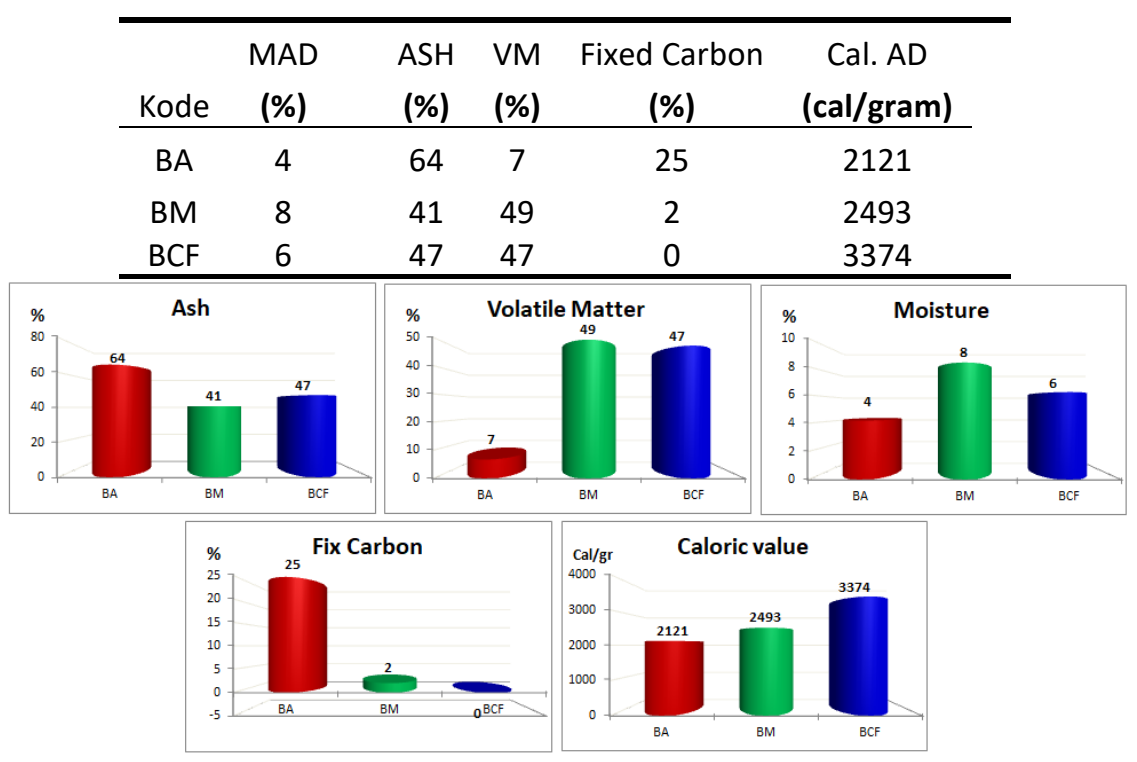

Fig. 7. Proximate analyses: the difference content of moisture, ash, volatile matter, fixed carbon, and caloric value between bottom ash and biomass fermented (as the raw material) and BCF as a mixed product.

Figure 7 explains that the water content value, volatile mater content, and ash of BCF are among of water content values, volatile mater content, and ash from it's raw material. These three parameters indicate that $\mathrm{BCF}$ is a mixture of two materials. While carbon fix of $\mathrm{BCF}$ is almost close to zero and caloric value is greater than both it's raw materials. This shows that through the combination of both raw materials namely BA and BM fermented causes the remaining carbon in BA can be burned again by adding volatile matter from BM, thereby increasing the caloric value of BCF mixture product. The presence of biomass here functions as self burning, thereby increasing temperature and burning the amount of carbon present in the material including fix carbon of bottom ash.

In this study, a preliminary trial of the BCF briquette as a substitute fuel in the boiler is done. Preliminary trials using substitution as much as $10 \%$ of total coal use in the industry. Observations of temperature and pressure at the bolier and gas emissions are carried out during 
the combustion process. The coal used in boiler engines is 30 tons per day but at the time of the preliminary trial only used $350 \mathrm{~kg}$ of $\mathrm{BCF}$.

As far the observations results of this preliminary trial show that the pressure increase from 6 bar to 7 bar uses $100 \%$ lumpy coal with calorific value of $5000 \mathrm{cal} / \mathrm{gram}$ takes 10 to 15 minutes. Whereas with a $10 \%$ BCF substitution, pressure increase in only takes 5 to 8 minutes for each addition of fuel. Thus the use of BCF increased combustion efficiency by $48 \%$. This preliminary trial shows that use of $10 \%$ BCF briquettes as a fuel substitution does not show or yet have not shown significant disruption to boiler performance.

Based on the observations results of emission tests, it shows that particulates, sulfur dioxide and nitrogen dioxide from the burning of BCF briquettes by $10 \%$ are below the required air quality standard threshold (Figure 8). The blue bar shows the emission from boiler 1 and red bar shows the emission from boiler 2. Boiler 2 is the boiler which does not use the BCF as a substitution of coal. To determine the effect of BCF briquettes on exhaust emissions, a comparison of emission values was carried out before the use of BCF briquettes $(t=1)$ and after the use of BCF briquettes $(t=2)$. The results of these two different time emissions are also compared to boilers without $\mathrm{BCF}$ substitution both $\mathrm{t}=1$ and $\mathrm{t}=2$. Generally, particulate emissions are almost close to the quality standard. While the value of sulfur dioxide and nitrogen dioxide emissions is far below the air quality standard threshold.

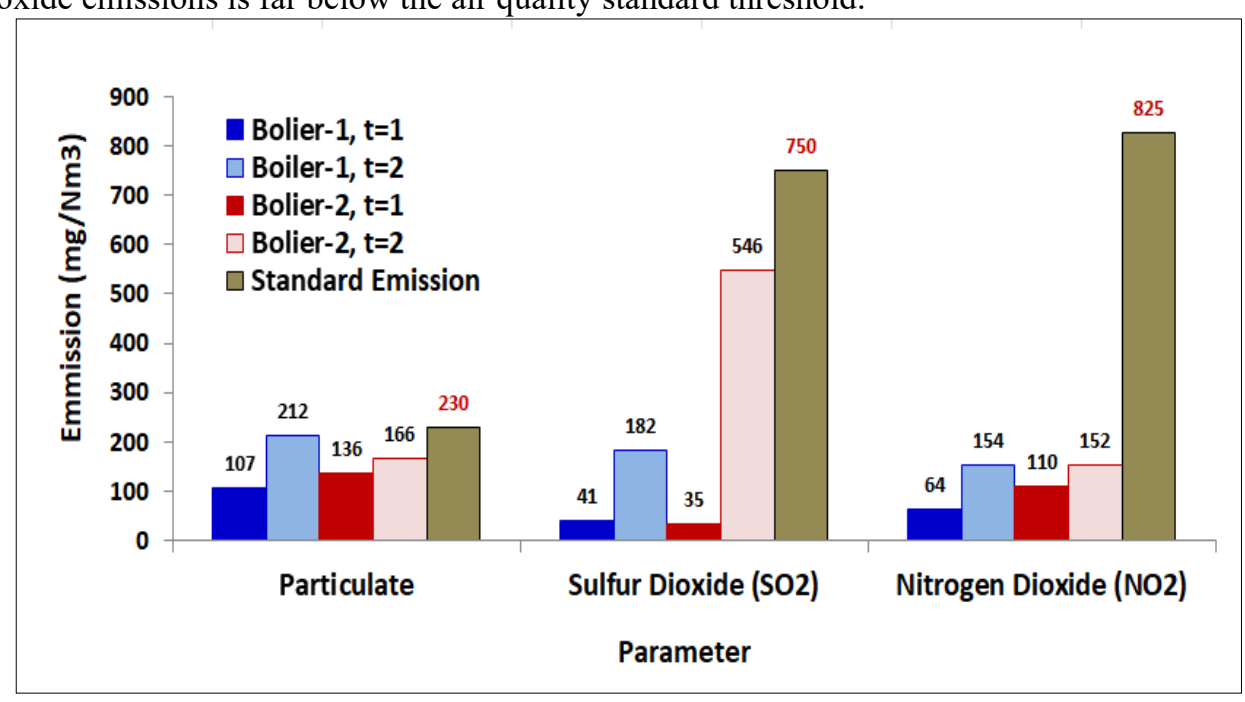

Fig. 8. Gas and particulate emission of BCF burning as a substituion of coal.

Based on Figure 8, both boiler 1 and boiler 2, there was an increase in the value of particulate emissions from $t=1$ to $t=2$, but the increase in boiler 1 was relatively more significant compared to the increase in particulate emissions in boiler 2 even though both boilers use the same lumpy coal fuel. From this data shows that the addition of biomass causes an increase in particulate emissions.

Particulates are solid materials dispersed in the air. A certain amount of particulate matter can enter the respiratory system, accumulate and interfere with lung performance. In certain frequencies and exposures, the accumulation of these particulates harm to lungs. Some researchers attribute these particulate emissions to the burning process of biomass fuels [13-15]. 
Sulfur dioxide is a sulfur and oxygen compound produced from the burning process of fossil fuels. Sulfur dioxide is a colorless gas but has a pungent odor and can cause irritation and diseases in the respiratory system. This $\mathrm{SO}_{2}$ can react with water, oxygen, and other materials in the air to form sulfide acids and trigger acid rain [16,17]. Sulfuric acid deposited on land can damage ecosystems, damage animals and aquatic plants, and damage various terrestrial plant life [18]. Figure 8 shows that two boilers produced an increase in $\mathrm{SO}_{2}$ emissions at $\mathrm{t}=2$. If it was compared with $\mathrm{SO}_{2}$ emissions at $\mathrm{t}=1$, it shows that there is a significant reduction in $\mathrm{SO}_{2}$ emissions after the use of BCF briquette as a substitution of coal.

Generally the sources of nitrogen oxides and nitrogen dioxide which are often called NOx come from burning fossil fuels, motor vehicles (especially diessel engines), excessive use of fertilizers, and increasing livestock (farming) activities $[16,19,20]$. As in perticult emissions, both in boiler 1 and in boiler 2, there was an increase in $\mathrm{NO}_{2}$ emissions from $\mathrm{t}=1$ to $\mathrm{t}=2$, even though both of them produced emission values below the quality standard. At condition $t=2$, $\mathrm{NO}_{2}$ emissions in boiler 1 are higher than boiler emissions 2 , even though both boilers use the same lumpy coal fuel. This shows that the $10 \%$ substitution of BCF briquettes has an effect on increasing $\mathrm{NO}_{2}$ emissions from biomass.

Based on Figure 8, in general, BCF briquette trials in boiler engines can only reduce the value of sulfur dioxide emissions. The coal type used in two boilers is the same, and it appears that only sulfur dioxide emissions make a very significant difference between boiler 1 (with $10 \% \mathrm{BCF}$ briquette substitution) and boiler 2 (without $\mathrm{BCF}$ briquette substitution). And the data analysis in this preliminary study proves that BCF has the potential as a fuel substitution for boiler engines. Aside from being a supporter of energy security, the utilization of BCF can provide one solution in the management and handling of waste and garbage.

\section{Conclusion}

BCF briquettes can be used as an alternative fuel, especially in boiler engines. In this study, $\mathrm{BCF}$ which is made from bottom ash and biomass of MSW that has been processed by "peuyeumisasi" methods gives a higher calorific value than both it's raw materials. Test results in bolier engines with a $10 \%$ substitution of the use of existing fuels gave an increase in combustion efficiency by $48 \%$ which particulate matter, $\mathrm{SO}_{2}$, and $\mathrm{NO}_{2}$ emission still lower than the required air quality standards.

\section{References}

[1] James, A.K., Thring, R.W., Helle, S., dan Ghuman, S.: Ash Management Review-Applications of Biomass Bottom Ash. Energies, 5, 3856-3873 ISSN 1996-1073 (2012)

[2] Jayaranjan, M.L.D., Hullebusch, E.D., dan Annachhatre, A.P.: Reuse Options for Coal Fred Power Plant Bottom Ash and Fy Ash. Rev Environ Sci Biotechnol (2014)

[3] Prasandha,A.F.E., Triwulan, and Ekaputri, J.J.: Paving Geopolimer Berbahan Dasar Bottom Ash and Sugar Cane Bagasse Ash (SCBA). Jurnal Teknik ITS, Vol. 4, No. 2 ISSN: 2337-3539 (2301-9271 Print) (2015)

[4] Santoso, I dan Roy, S.K.: Pengaruh Penggunaan Bottom Ash Terhadap Karakteristik Campuran Aspal Beton. Jurnal Dimensi Teknik Sipil, Vol.5, No. 2, pp. $75-81$ (2003) 
[5] Estiaty, L.M., Fatimah, D., dan Widodo.: Bio-Coal Briquettes Using Low-Grade Coal. Procedding on Global Colloquium on GeoSciences and Engineering, IOP Conf. Series: Earth and Environmental Science 118012066 (2017)

[6] Slamet, S. dan Gunawan, B.: Karakterisasi Biobriket Campuran Bottom Ash dan Biomassa Melalui Proses Karbonasi Sebagai Bahan Bakar Padat. Prodising Seminar Nasional Sains dan Teknologi Ke-3, Fakultas Teknik Universitas Muhammadiyah Jakarta. ISSN: 2407-1846 EISN: 2460-8416 (2016)

[7] Yüksel, I., Özkan, Ö., dan Bilir, T.: Production of briquette with bottom ash. [Kazanalti külü ile briket üretimi]. Journal of the Faculty of Engineering and Architecture of Gazi University, 21(3), 527532 (2006)

[8] Wardiasih, S., Marganingrum, D., and Ainun, S.: Identifikasi Potensi Pemanfaatan Sampah Organik Pasar Cihaurgeulis Menjadi Bahan Bakar Biomassa. Reka Lingkungan-Jurnal Onlin Teknik Lingkungan ITENAS, No. 1, Vol. 1 (2018)

[9] Afomah, A.N and Ghabo, A.: The Physical, Proximate and Ultimate Analysis of Rice Husk Briquettes Produced from a Vibratory Block Mould Briquetting Machine. Vol. 2 Issue 5. International Journal of Innovative Science, Engineering \& Technology (2015)

[10] Kwaghger, A., Enyejoh, L. A. and Iortyer, H. A.: The Development of Equations for Estimating High Heating Values from Proximate and Ultimate Analysis for Some Selected Indigenous Fuel Woods. European Journal of Engineering and Technology. Vol. 5 No. 3, Pages: 21-33, ISSN 20565860. Progressive Academic Publishing, UK (2017)

[11] Hussaian, S., Sooro, S.A., Aziz, S, Ali, A., and Ali, N.: Ultimate and Proximate Analysis of Coal Briquettes from Lakhara Lignite, Biomass and Plastic Waste. Engineering Science and Technology International Research Journal, Vol. 2, No. 4. Page: 32-38 (2018)

[12] Krizan, M., Kristof, K., Angelovfic, M., Jobbagy, J., Urbanovicova, O.: Energy potential of densified biomass from maize straw in form of pellets and briquettes. Agronomy Research 16(2), 474 $482(2018)$

[13] Johanssona, L.S., Tullina, C., Lecknerb, B., and Sj'ovalla, P.: Particle emissions from biomass combustion in small combustors. Biomass and Bioenergy, 25, pp. 435-446 (2003)

[14] Amaral, S/ S., de Carvalho Jr, J.A., Costa, M.A.M, and Pinheiro, C.: Particulate Matter Emission Factors for Biomass Combustion. Atmosphere, 7, 141 (2016)

[15] Lajili, Marzouk.: Assessments of Gaseous and Particulate Matter Emissions from Biomass Combustion and their Effect on Human Health. Biomedical Journal Science and Technical Research, Vol. 2 (17) (2019)

[16] Enger, E.D and Smith, B.F.: Environemntal Science: A study of Interrelationships. Publisher: Kevin T. Kane, WBC/McGraw-Hill, pp. 352-353 (1998)

[17] Okedere, O.B., Sonibare. J.A., Ajala, O.E., Adesina,O.A. and Elehinafe, F.: Estimation of sulphur dioxide emission from consumption of premium motor spirit and automotive gas oil in Nigeria. Cogent Environmental Science, 3: 1330456, pp. 2-17(2017)

[18] Smith,S.J., Aardenne, J.van, Klimont, Z., Andres, R. J., Volke, A., and Arias, S.D.: Anthropogenic sulfur dioxide emissions: 1850-2005. Atmosferic Chemistry and Physics. 11, 1101-1116 (2011)

[19] Mwangi, J.K, Lee, W.J., Tsai, J.H., and Wu, T.S.: Emission Reductions of Nitrogen Oxides, Particulate Matter and Polycyclic Aromatic Hydrocarbons by Using Microalgae Biodiesel, Butanol and Water in Diesel Engine. Aerosol and Air Quality Research, 15: 901-914, ISSN: 1680-8584 (2015) [20] Liu, L., Zhang, X, Xu, W., Liu, X., Li, Y., Lu., X., Zhang, Y., and Shang, W.: Temporal characteristic so fatmospheric ammonia and nitrogen dioxide over China based on emission data,satellite observations and atmospheric transport modeling since1980. Atmosferic, Chemistry, and Physics., 17, 9365-9378 (2017) 